\title{
Formation of spiritual and moral ideology and methodology of innovative economic development
}

\author{
Nikolay Shevkunov ${ }^{1, *}$, Anna Zigunova ${ }^{1}$, Irina Logvinova ${ }^{1}$, Natalya Gorkovenko ${ }^{1}$, \\ Lyudmila Kravchenko ${ }^{2}$, Natalia Gromakova ${ }^{2}$ \\ ${ }^{1}$ Rostov State Transport University, sq. Rostovskogo Strelkovogo Polka Narodnogo Opolcheniya, \\ 2, Rostov-on-Don, Russia \\ ${ }^{2}$ Don State Technical University, Gagarin sq.,1, 344000, Rostov-on-Don, Russia
}

\begin{abstract}
The article presents the formation and development of the Russian economy in the field of ideology and methodology, taking into account the spiritual and moral laws and the meaning of modern life. Spiritual and moral ideology is considered from the perspective of economic problems and expectations of modern society. The analysis of economic goals in the historical continuum and in terms of spiritual values is carried out. The object and object of the economy are determined from the position of the Christian worldview. The article analyzes the formation of methodological approaches of economic science from the position of Christianity. The arguments in favor of the fact that spiritual laws in Christianity do not contradict, but represent the necessary basis for the considered methodological approaches, taking into account which normal progressive innovative economic development is possible.
\end{abstract}

\section{Introduction}

The formation and development of the national innovation system is a key task of Russia's strategic competitiveness, its adaptation to the changing requirements of the external and internal environment. The introduction of sanctions against the Russian economy, restricting access to world markets of technology, financial resources and changing directions of foreign economic cooperation, coincided with the need to address priority define the vector of economic development associated with the definition of the main goals of the economy. This, in turn, determines the need for the formation of a universal social ideology aimed at the development of the human personality, the formation of spiritual foundations in it in the first place, without which

\footnotetext{
* Corresponding author: shevkunov-no@mail.ru
} 
no economic development, including innovation, is possible, about which so much has been said recently [1]. Without man there is no economy. And man is created in the image and likeness of God. A spiritually-moral economy strengthened ideologically and methodologically can have a decisive impact on the creation, preservation and development of innovative advantages of the Russian economy.

Scientific researches in the field of formation of spiritual and moral ideology of economic development demand expansion of theoretical and conceptual representations, development of methodology in this multifaceted sphere [2]. The scientific novelty of the research lies in the development of ideology and methodology reflecting the spiritual and moral paradigm and human-oriented policy. The creation of a spiritual and moral ideological platform will have a direct positive impact on the quality and efficiency of management of the national innovation system, and, consequently, on economic development in General.

The fundamental scientific task of research in this direction is to transform the methodological basis of economic theory and the study of economic processes from the position of spiritual and moral approach, the expansion of conceptual and theoretical ideas in the field of universology and methodology.

\section{Spiritual and moral ideology of innovative economic development}

The French personalist philosopher Emmanuel Mounier wrote: "the Interaction of economic and spiritual principles in the human world sets us the measure and limits in which moral judgments are significant for the material order." Thus, the construction of the economic system of any state requires, first of all, the creation and observance of laws of spiritual and moral order, which must be observed for successful economic development as well as legal laws, laws of physics and mathematics.

Approaching the study of the question of spiritual and moral economy as a new type of reasonable rational management, it should be noted the following. Today in the conditions of global crisis of world economy of market type the problem of formation, strengthening and development of a new economic way with orientation on the person, on his internal world, on improvement of moral and spiritual properties and qualities becomes actual [3].

Unfortunately, the principles of the formed consumer relation to all resources surrounding the person became hackneyed expressions: "you want to live-be able to turn", "take everything from life", which fundamentally contradict the main law of spiritual life: "Search first for the Kingdom of God and his truth, and all this will be added to you". And the Kingdom of God, as we know, "is within us."

On holidays, at corporate feasts and a narrow family circle, congratulatory speeches are associated with the wishes of physical health and happiness, which are directly related to the most important thing: "more money". And money solves all problems. This approach stems from subjectivist marginalism, which put the pleasure of consuming goods by individual subjects in the first place. Thus, the message is given: "look first for money, and the rest will be added to you." And this is happening in Russia, in a multi-confessional state, where the basis of religion and faith is formed by Orthodox Christianity, Islam and Buddhism.

Mass media representing the face of the state, the distribution and broadcasting of which is carried out throughout the country and abroad, are focused on the formation of consumer, materialistic demand. Advertising provokes people to constantly meet the 
needs imposed by the stereotypes of supposedly modern man [4]. And if the formed personalities on the basis of, for example, the code of builders of communism or Christian spiritual and moral traditions have a certain immunity, then the younger generation without an ideological basis is much less likely to resist this wave of purposeful influence on the inner world, on the way of thoughts and feelings.

The meaning of modern life is the maximum satisfaction of passionate needs. To buy a status car and prestigious real estate, to have a rest on the advertised resorts, to visit expensive restaurants-here the incomplete list of tasks within the purpose of life of consumer society. Raising social status develops popularity [5]. The desire to acquire luxury goods and the desire to "cool" to relax leads to voluptuousness. Provides both a high fee, which leads to the formation of greed. Moreover, the spiritual law of affinity of vices strengthens their joint destructive action. The question arises: "what was the status of Jesus Christ, the incarnate God himself?" There was no high hierarchical social status. Then what should the prevailing majority of modern society aspire to?

Given the above, we can identify the following causes of spiritual and moral crisis in economic development (Figure 1).

However, to talk about the spiritual now is not fashionable and not in trend. At every election debate, none of the candidates for high public office said a word about spiritual laws. Only Mr. Baburin S.N. touched upon the question of the revival of the Russian spirit through the constitutional rehabilitation of Orthodoxy.

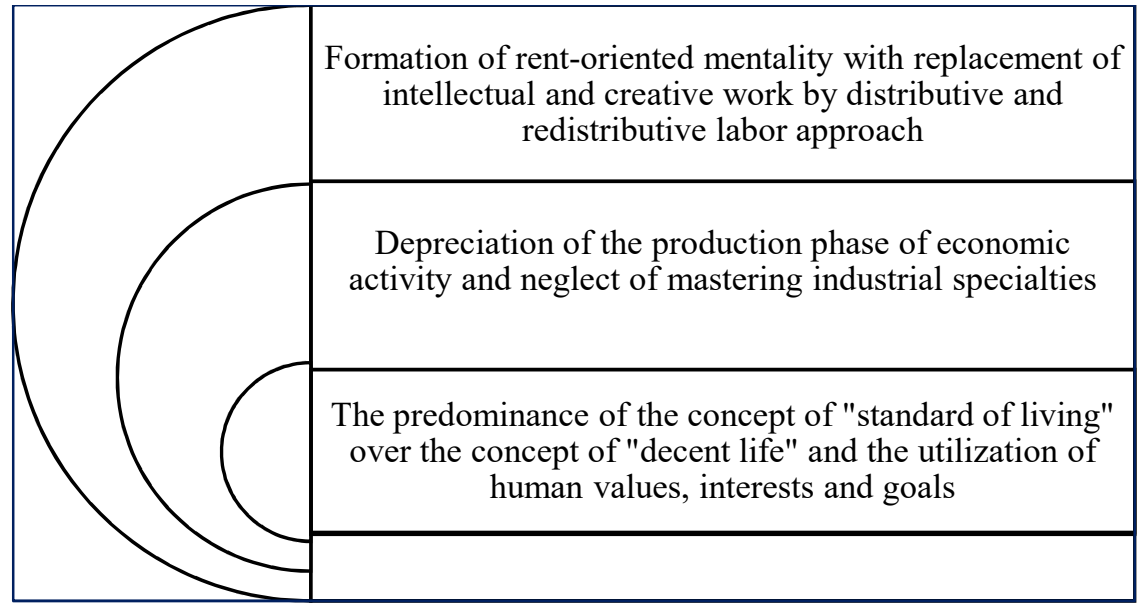

Fig 1. Causes of spiritual and moral crisis in economic development

\section{The goal of the economy}

The term economy was one of the first introduced by the ancient Greek philosopher Xenophon in his work "Oikonomika", which in Russian translation sounds like "Domostroy". It tells about the rules of household management. Another ancient Greek philosopher Aristotle defined Economics as the science of intelligent management. Aristotle called the enrichment and acquisition of profit at the expense of, for example, usury and speculative operations chrematistics and considered the phenomenon negative and unnatural for man. The purpose of Economics according to Aristotle is to create goods to meet the immediate needs of man. Christianity also teaches: "give us this day our daily bread." 
The purpose of the economy, both market and planned is to maximize the satisfaction of the needs of society in material goods with minimal labor and resources [6].

The purpose of the economy, built on the principles of Christianity is primarily in the spiritualization, transformation and connection of man with God. Questions of material well-being are secondary, the solution of which is necessary due to the fact that a person can not live without food, clothing, housing, etc.But the vector of human aspiration is directed towards the salvation of the soul, and not the body, the existence of which, as everyone knows, of course.

We are not talking about the fact that the material is not necessary. But to torment the soul and all aspirations to direct on extraction of material values Christianity in a root is rejected.

In an economy focused on spiritual values, all its main priorities are subject to revision.

The goal of any human labor activity in accordance with the ideas of Orthodox Christianity is humility. In the words of Isaac Syrian " the reward is no longer virtue and not work for her, and born of them humility." "The reward is not for doing, but for humility. "Humility is the state of man that arises when he sees his sins. The provision of "daily bread", that is, material goods necessary for life, should be in abundance and no more.

Buying luxury real estate, cars, clothes, a person does not get a sublime state of spirituality and happiness. Rather, on the contrary, pride, self-love, glory and vanity grow, which lead to spiritual and bodily destruction.

If we do not change the direction of economic development, the threat of destruction on a national scale increases.

\section{The object and subject of Economics from the position of Christianity}

In Orthodox Christianity, God is the spirit, love, humility and doctor for the human soul, which is enclosed in a passionate, corruptible and mortal body in earthly life. But even in this earthly life, a person can become happy in the true sense by connecting with God.

Christianity offers a perfectly understandable and clear system of living with God. All spiritual laws operate for all spheres of this life, including economic.

As is known, the object of research in economic theory is social production. In this statement the majority of economists-theorists, representatives of various economic schools agreed. But the main production force is man [7]. And in General all social production depends on the person, his properties and qualities. Economic relations are formed in a certain social environment. The theoretical study of only objects and means of labor, as well as living labor without the study of the main participant in economic relations is impossible and useless, even because the main purpose of social production is to satisfy the spiritual and physical needs of the person and the development of the economy is also impossible without the main transmission link, which [8].

Man, in the words of Leo Tolstoy, "is aware of himself as a bodily person who wants the good only for himself" and "a disembodied spirit who wants the good of the whole world." "Live man for the body - and life is Woe, because the body suffers, sick and dies. Live for the spirit - and life is good, because for the spirit there is no suffering, no disease, no death. "The spirit determines all spheres of human life. According to the 
main idea of Christianity, personality is indestructible. Therefore, as an object of research in economic theory, we propose to choose the spiritual personality of a person in economic relations. And accordingly, the subject of economic theory - economic relations that form the spiritual personality of man.

The formation of the spiritual personality requires an ideology that, in contrast to the secular consumer ideology, will form immunity to the ubiquitous modern appeals of the mass media about the thoughtless and senseless, irrepressible satisfaction of base instincts, when the personal dissolves into the impersonal carnal, passion comes and begins to possess a person uncontrollably.

\section{Formation of methodology of economy from the position of Christianity}

As you know, the basis of any methodology is philosophy. Therefore, considering General scientific methodological approaches and methodological approaches to the study of Economics, it is necessary to initially summarize the philosophical basis.

Let us begin the study of fundamental philosophical trends with idealism. Idealism, then, is a worldview that characterizes everything as a manifestation of an idea, a mind, or a spirit. The position of Christianity in this is consistent with this interpretation of the worldview, proclaiming the essence of God as the omnipresent spirit, which is the Creator of the whole world. But Christianity defines God not only as spirit, and the most important thing is that God is love. Without love, even with justice, there is no truth [9].

Idealism is divided into two directions. One of these trends is subjective idealism. The ideological ancestor of this philosophical trend is the ancient philosopher Socrates, who believed that the material world surrounding man is subjective. Socrates showed the spiritual sphere of consciousness as an independent sphere of reality, revealed the importance of considering the personality of man. The greatest virtue in Socrates is recognized as the moderation of man in everything. His idea that the less a person needs material goods, the closer he approaches God, is close to the Christian doctrine [10].

The very same concept of subjectivism and its main idea proposed by Rene Descartes. Subjectivism is defined by him as " the view of consciousness as the primordial given, while everything else is the form, content or result of the creativity of consciousness." Everyone knows Descartes 'saying:" I Think-therefore, I exist."But the spiritual sphere in the Christian view according to our contemporary Professor of theology of the Moscow theological Academy Alexei Ilyich Osipov is nothing but the thoughts of man. And the spiritual sphere in Christianity is certainly primary in relation to the material physical world. The purpose of Christianity is the salvation of the human person by observing the new Testament commandments, which are aimed at cleansing thoughts and bringing a person to a normal state [11].

The founder of subjective idealism is called George Berkeley, the British philosopher. He developed the idea that " being is either that which is perceived or that which perceives." Berkeley's main message was that only spirit exists. The main provisions of the concept are "to exist is to be perceived" and "to exist is to perceive". By the way, Berkeley in his theory in a peculiar way defended religious Christian ideas from spreading and gaining strength at the time of materialistic beliefs [12].

The position of subjective idealism about the surrounding material world as an illusory world, the world of dreams is confirmed by the Christian understanding of this earthly mortal world and the words of Jesus Christ: "the Kingdom of God is within you. "But there is a deeper meaning in these words. Eternity itself and the real world is 
within man. And a person already in this earthly life can feel the fullness of joy and integrity of the state in the Kingdom of God while observing the gospel commandments [13].

Let us now turn to the successor of subjective idealism in the study of social production - the General scientific subjectivist methodological approach. The object of economic research in this approach is a free and sovereign economic entity that forms the subjective value or value of spiritual and material goods in the conditions of limited resources and unlimited needs [14]. The subject from the position of the proposal is an enterprise that produces products, provides services, performs work. This subject owns private property, which should be inviolable. From the point of view of demand, the subject under study is a free and sovereign consumer or buyer. From the Christian point of view, God always gives man complete freedom of choice. The main theory of the subjectivist methodological approach is the economic theory of choice taking into account utility and need. And God also according to Christian dogmas does everything only for the benefit of man. Freedom of choice and benefit for a person are the main conditions for the implementation of both the subjectivist methodological approach and the Christian doctrine.

From the General scientific subjective methodological approach follows the General economic methodological approach, called consumer. The essence of the consumer approach is that the value of spiritual and material goods is formed by their utility for an individual subject.

Speaking about the economic schools adhering to the subjectivist, and therefore consumer approach, it is necessary to allocate the following.

First, they are mercantilists, who believe that the basis of the wealth of the state and the satisfaction of all the needs of citizens is formed by trade, and above all, foreign trade with the predominance of exports over imports. The founders of mercantilism consider Thomas Man, Jean-Baptiste Colbert, Anthony Serra, Samuel Fortrey. The concept of mercantilism is closely related to state protectionism [15].

Second, the rise of the consumer approach is associated with marginalism. Marginalism lays the foundations of the neoclassical trend in economic theory as an alternative to classical theories.

The founders of marginalism are Carl Menger, William Stanley Jevons and Leon Walras.

Karl Menger believed that the value of various goods has a pronounced subjective character and it does not exist as such outside of human consciousness.

William Stanley Jevons considered the main problem of economic science to be the maximum satisfaction of man in pleasure and liberation from suffering. He made a great contribution to the development of mathematical analysis in economic theory.

Leon Valras developed the theory of economic equilibrium. He adhered to the subjective theory of value, and promoted the mathematization of Economics.

Marginalism uses analysis methods based on marginal concepts of utility, productivity, cost, income, and others.

Marginalists believed that a person, satisfying all his needs and freeing himself from suffering, should be rational.

Consider the concept of marginalists from the perspective of Christianity. The question is to what extent one should indulge in pleasure. If the enjoyment of goods makes him their slave and a person is unable to control himself as a person, it means that he commits sin and suffers accordingly. And how can you then free yourself from suffering while indulging in pleasures as much as possible? That's the whole point, that it is impossible to be rational and reasonable and at the same time indulge in maximum 
satisfaction. After all, the main virtue of Socrates, namely, he is the founder of subjective idealism, is moderation, that is, the knowledge of measure. And Christian doctrine may eat, but do not overeat, do not do not drink, but don't get drunk, can and should marry, but not in fornication.

\section{Conclusions}

Thus, we can state the fact that subjective idealism is close to the Christian worldview, but speculative mercantilism and irrepressible pleasure marginalism distorted the original correct guidelines of Socrates.

The consumer methodological approach in Economics, which is based on subjective idealism, from the position of Christianity can get its development in the direction of what is really useful for a person in satisfying needs, obtaining pleasure and reducing suffering, and what is on the contrary - harmful and destructive.

For example, the Orthodox Christian Saint Basil the Great considers "actual needs "to be the measure of permissible expenses. St. Clement of Alexandria of the Anglican Church proves that " it is precisely those objects which are not difficult to acquire that are most useful to people." "Scripture requires us not to renounce property, but to renounce excessive attachment to property." St. John Chrysostom commands "to be frugal in view of the poverty of other people, as abstaining from waste, you get the opportunity to help others." He also argues that "wealth is a distorted pursuit of eternal life."

Objective idealism, the ancestor of which is another great ancient Greek philosopher Plato, as the basis of the entire universe sees the objective spiritual principle. There are also his representatives in German classical philosophy in the person of Schelling and Hegel. In an economy whose aim is the rational provision of man with all goods, objective idealism seems not to be perceived as a methodological basis because social production exists for man and not for the highest superindividual principle.

The dialectical materialism of Karl Marx and Friedrich Engels asserts the primacy of matter, but defines matter as a "mental abstraction". What is matter from a scientific point of view, no one knows until the end, the boundaries of the material and immaterial are not defined: "eternity in time and infinity in space." Dialectical materialism sees the goal of economy as a comprehensive self-development of man, which also does not contradict the Christian worldview in any way.

In Christianity, in fact, subjective idealism is combined with objective idealism and materialism (Figure 2).

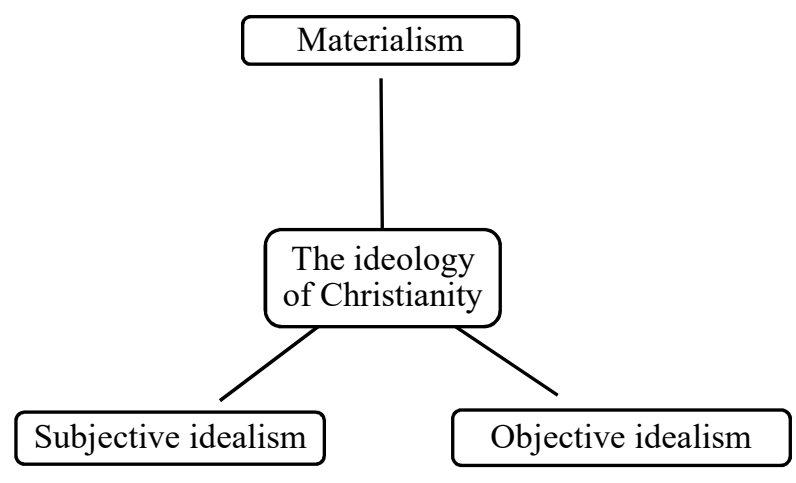


Fig. 2. Unification of elements of materialism, subjective and objective idealism in Christian ideology

The Creator of the whole world, who is spirit, love, humility, physician and Saviour, is naturally perceived as the objective Supreme mind and the absolute subject, but each person, being the image and likeness of God, is endowed with complete freedom to choose and change his life path, both material and spiritual. It is from the consciousness and thoughts of man himself that his salvation and communion with God depend, without which no normal economic development is possible.

\section{References}

1. S. Mezentsev, Economics and Entrepreneurship, 79-85 (2018)

2. N. Popova, Education and Science, 161-181 (2017)

3. P. Tolkachev, Philosophy of economy, 121-128 (2011)

4. N. Manuilov, New Economics and regional science, 67-71 (2017)

5. N. Kulikova, D. Karateev, Discussion, 57-65 (2014)

6. E. Nikandrova, Proceedings of St. Petersburg state University of Economics, 116119 (2014)

7. B. Salikhov, Scientific notes of the Russian state social University, 14-25 (2010)

8. T. Yudina, Problems of modern economy, 477-479 (2009)

9. A. Yegorychev, In the world of scientific discoveries, 795-814 (2014)

10. M. Gelvanovsky, The standard of living of the population of the regions of Russia, 145-151 (2014)

11. S. Kozlova, Finance and credit, 46-60 (2016)

12. M. Ulanov, Caspian region: politics, economy, culture, 292-299 (2015)

13. M. Voronkova, Citizen and the law, 38-48 (2010)

14. O. Nifaeva, Scientific works of the Free economic society of Russia, 503-514 (2013)

15. T. Ivanova, Manager, 64-69 (2018) 